\title{
INTERNATIONAL BANKRUPTCY: IN DEFENSE OF UNIVERSALISM
}

\author{
Andrew T. Guzman*
}

\section{INTRODUCTION}

The globalization of business activity is rightfully celebrated as one of the triumphs of the second half of the twentieth century. The benefits stemming from the globalization of commerce are substantial, but international transactions also bring with them important challenges for the world's legal systems. Traditionally, national governments could focus on their domestic economies without undue attention to international issues. Today, however, a country's policymakers must respond to the growth in international business activity with appropriate legal changes. Failure to do so will cause their legal regimes to fall further and further out of step with the needs of the global marketplace. The exact content of the changes to be made, however, remains uncertain. This Article attempts to address one of the many international business issues that is forcing us to change the way we think about regulating cross-border activity - the treatment of transnational bankruptcy.

It is a fact of economic life that businesses fail. The growth of international business, therefore, has brought with it a growth in the number of international business failures. ${ }^{1}$ In recent years, the increased number of international insolvencies has brought attention to the question of how to deal with transnational bankruptcies. ${ }^{2}$ That

* Acting Professor, Boalt Hall School of Law, University of California at Berkeley. B.S. Toronto, 1990; J.D., Ph.D. Harvard, 1996. - Ed. I owe thanks to Lucian Bebchuk, Richard Brooks, Richard Buxbaum, Stephen Choi, Kevin Davis, Robert Cooter, Jesse Fried, Lynn LoPucki, Robert Rasmussen, Dhan Shivakumar, Frederick Tung, Elizabeth Warren, John Yoo, and participants at the Boalt Hall Law and Economics Seminar for helpful comments and discussions. Special thanks to Jeannie Sears and Nicholas James. Melissa Kennedy and Ryan Waterman provided invaluable research assistance.

1. Well-known examples of transnational bankruptcies include Maxwell Communications, see In re Maxwell Communication Corp., 170 B.R. 800 (Bankr. S.D.N.Y. 1994); Bank of Credit \& Commerce International (BCCI), see Hal S. Scott, Supervision of International Banking Post-BCCI, 8 GA. ST. U. L. REV. 487 (1992); and Olympia and York, see In re Olympia \& York Devs. Ltd. [1993] 12 O.R.3d 500.

2. See Lucian A. Bebchuk \& Andrew T. Guzman, An Economic Analysis of Transnational Bankruptcies, 42 J.L. \& ECON. 775 (1999); Douglas G. Boshkoff, Some Gloomy Thoughts Concerning Cross-Border Insolvencies, 72 WASH. U. L.Q. 931 (1994); Lynn M. LoPucki, Cooperation in International Bankruptcy: A Post-Universalist Approach, 84 CORNELL L. REv. 696 (1999) [hereinafter LoPucki, Cooperation]; Robert K. Rasmussen, $A$ New Approach to Transnational Insolvencies, 19 MICH. J. INT'L L. 1 (1997); Jay Lawrence Westbrook, Choice of Avoidance Law in Global Insolvencies, 17 BROOK. J. INT'L L. 499 
said, it must be noted that cross-border business failures are new to neither the business world nor academia. Nor has there been a great shift in the perspective of legal academics over the years. In an article published in the Harvard Law Review in 1888, John Lowell wrote: "It is obvious that ... it would be better in nine cases out of ten that all settlements of insolvent debtors with their creditors should be made in a single proceeding, and generally at a single place."3 One hundred years later, the call for "universalism" continues: "[A]ll questions of importance to the distribution of the debtor's assets should be governed by the law of the debtor's principal place of business." 4 Legislators $^{5}$ and judges, however, have resisted these academic proposals out of concern for the welfare of domestic creditors. ${ }^{6}$ This Article seeks to address that concern directly.

(1991) [hereinafter Westbrook, Choice of Law]; Jay Lawrence Westbrook, Theory and Pragmatism in Global Insolvencies: Choice of Law and Choice of Forum, 65 AM. BANKR. L.J. 457 (1991) [hereinafter Westbrook, Theory and Pragmatism].

3. John Lowell, Conflict of Laws as Applied to Assignments of Creditors, 1 HARV. L. REV. 259, 264 (1888).

4. Donald T. Trautman, Foreign Creditors in American Bankruptcy Proceedings, 29 HARV. INT'L L.J. 49, 58 (1988) [hereinafter Trautman, Foreign Creditors]. Similar statements can be found in almost any article on the subject. See, e.g., Todd Kraft \& Allison Aranson, Transnational Bankruptcies: Section 304 and Beyond, 1993 COLUM. BUS. L. REV. 329,364 ("A system that brings together all the creditors, and all the debtor's property, for a single distribution is the most efficient and equitable system possible."); Westbrook, Choice of Law, supra note 2, at 515 ("Universality ... has long been accepted as the proper goal of international bankruptcy law by leading writers."); Jay L. Westbrook \& Donald T. Trautman, Conflict of Laws Issues in International Insolvencies, in CURRENT DEVELOPMENTS IN INTERNATIONAL AND COMPARATIVE CORPORATE INSOLVENCY LAW 655,667 (Jacob S. Ziegel ed., 1994) ("In general, the goal in developing choice of law rules should be to apply the home-country law as pervasively as possible."). But see LoPucki, supra note 2, passim (arguing against universalism); Stacey A. Morales \& Barbara A. Deutcsh, Bankruptcy Code Section 304 and U.S. Recognition of Foreign Bankruptcies: The Tyranny of Comity, 39 BUS. LAW. 1573, 1595-96 (1984) (arguing for retention of U.S. jurisdiction over a foreign debtor's U.S. assets "unless the standards of section 304 clearly mandate that such control be relinquished through the mechanism of turnover").

5. See REPORT OF THE COMMISSION ON THE BANKRUPTCY LAWS OF THE UNITED STATES, H.R. DOC. NO. 93-137, at 71 (1973); H.R. REP. No. 95-595, at 324-25 (1977). The statute itself expresses concern for local creditors, instructing courts to consider "protection of claim holders in the United States against prejudice and inconvenience." 11 U.S.C. \& 304(c)(2).

6. This characterization is accurate both in the United States and in other countries, but this Article focuses on the United States because it is the jurisdiction with which I am familiar and because "American statutory law goes further than the law of any other industrialized nation in authorizing cooperation with foreign insolvency regimes." Douglas G. Boshkoff, Some Gloomy Thought Concerning Cross-Border Insolvencies, 72 Wash. U. L.Q. 931, 932 (1994). By examining the American situation, we learn a great deal about why there is not a greater global push for universality. For a discussion of the laws of various countries, see INTERNATIONAL LOAN WORKOUTS AND BANKRUPTCIES (Richard A. Gitlin \& Rona R. Mears eds., 1989). For a discussion of attempts at multilateral solutions, see Michael Bogdan, The Nordic Bankruptcy Convention, in CURRENT DEVELOPMENTS IN INTERNATIONAL AND COMPARATIVE CORPORATE INSOLVENCY LAW, supra note 4, at 701; Kraft \& Aranson, supra note 4, at 351-61; Donald T. Trautman et al., Four Models for International Bankruptcy, 41 AM. J. COMP. L. 573 (1993). 
In simplified terms, two polar approaches to the adjudication of international insolvencies exist: universalism and territorialism. In its purest form, universalism would have all bankruptcy claims adjudicated within the debtor's "home country" and would apply the substantive laws of that country. Based on the law of that jurisdiction, the assets of the firm would be distributed to creditors around the world? The alternative to universalism is territorialism or, more pejoratively, the "grab rule." Under this rule, "the courts in each national jurisdiction seize the property physically within their control and distribute it according to local rules." Critiques of the territorialist position are numerous and will not be repeated in detail here. ${ }^{10}$ For present purposes, it is enough to note that proponents of universalism argue that it would yield a variety of benefits, including a more efficient ex ante allocation of capital, ${ }^{11}$ reduced administrative costs due to a reduction in the number of proceedings, ${ }^{12}$ avoidance of forum shopping and the race to file, ${ }^{13}$ facilitated reorganizations, ${ }^{14}$ increased liquidation value ${ }^{15}$ and the provision of clarity and certainty to all parties. ${ }^{16}$ The most

7. Several variations on universality have been proposed. A complete description of the alternatives is beyond the scope of this Article. One possible form of universalism grants discretion to local courts regarding the turning over of assets to the home jurisdiction. This approach has been termed "modified universalism." See Westbrook, Choice of Law, supra note 2 , at 517. An alternative approach permits local courts to carry out a "secondary bankruptcy proceeding" - distributing assets in order to protect local creditors and then turning any remaining assets over to the main proceeding. This is the approach advocated by the UNCITRAL Model Law on Cross Border Insolvency. See UNITED NATIONS, UNCITRAL MODEL LAW ON CROSS BORDER INSOLVENCY WITH GUIDE TO ENACTMENT (1999); see also Andre J. Berends, UNICTRAL Model Law on Cross-Border Insolvency: A Comprehensive Overview, 6 TUL. J. INT'L \& COMP. L. 309 (1998).

8. Westbrook, Theory and Pragmatism, supra note 2, at 513. Universalism and territorialism are, of course, merely the endpoints of a spectrum. Although proposals tend to be clearly more toward one end or the other, most advocate a position somewhere between the extremes. Most recently, a variation on territorialism, called "cooperative territoriality" has been proposed. This regime is similar to territorialism, with the added feature that countries would cooperate to reduce the burden of filing in multiple jurisdictions; share information regarding distributions; allow the joint sale of assets when necessary to maximize value; facilitate the seizure and return of assets subject to avoidable transfers; and allow the voluntary investment by representatives in one country in the debtor's reorganization in another. See LoPucki, supra note 2, at 742.

9. Westbrook, Choice of Law, supra note 2, at 513.

10. See generally Bebchuk \& Guzman, supra note 2; Rasmussen, supra note 2; Westbrook, Choice of Law, supra note 2; Westbrook, Theory and Pragmatism, supra note 2.

11. See Bebchuk \& Guzman, supra note 2.

12. See id. at 778.

13. See Rasmussen, supra note 2, at 6-10.

14. See Westbrook, Theory and Pragmatism, supra note 2, at 465.

15. See Rasmussen, supra note 2, at 18.

16. See Westbrook, Theory and Pragmatism, supra note 2; Jay L. Westbrook, Universal Participation in Transnational Bankruptcies, in MAKING COMMERCIAL LAW: ESSAYS IN HONOUR OF ROY GOODE 419, 421 (Ross Cranston ed., 1997) ("Territorialism produces distributions that are a function of local priorities and the presence of a greater abundance of 
eloquent and effective proponent of universalism in the last decade has been Jay Westbrook, who has also contributed to this symposium. ${ }^{17}$ Although Professor Westbrook and I approach the subject of international bankruptcies from somewhat different perspectives, we hold very similar views of the preferred policy prescription. With this in mind, and in the interest of space, I will not address his arguments directly in this Article. If I did, it would be primarily to express my support for his views.

Territorialist objections to universalism center on the treatment of small, local creditors. United States courts often express reluctance to turn assets over to foreign jurisdictions when doing so would put local creditors at a disadvantage, ex post, relative to foreign creditors. The academic criticism of universalism is similarly focused on the treatment of local creditors, although the argument is somewhat more subtle. The argument against universalism rests on the belief that "universalism would be unpredictable to all but the largest creditors of multinational companies."18 It is claimed that only they would have enough at stake to warrant adjustment. ${ }^{19}$ This Article attempts to make progress toward resolving the debate between universalists and territorialists through an analysis of this most central element of the criticism of universalism. Is there a class of creditors that is better off under territorialism? If so, how many such creditors are there and how much do they stand to lose? What conclusions can we reach about overall social welfare in the face of these concerns?

To understand why the debate needs to focus on what are termed "nonadjusting creditors," one needs to recognize that in a competitive market - the most reasonable assumption for capital markets "adjusting creditors" (those who adjust the terms of their lending to reflect the risks they face) will earn a market rate of return regardless of the choice of bankruptcy rule. ${ }^{20}$ If all creditors are adjusting, the debtor will bear all costs imposed by the choice of law rule because competitive pressures will prevent the creditors from earning more or less than the risk-adjusted market rate. In a particular case, of course, local creditors may be at a disadvantage, from an ex post perspective,

assets in one jurisdiction than in another .... The distributions are always unpredictable and often unfair.").

17. See Jay Lawrence Westbrook, A Global Solution to Multinational Default, $98 \mathrm{MICH}$. L. REV. 2276 (2000).

18. LoPucki, Cooperation, supra note 2, at 712.

19. See id.

20. The terms "adjusting" and "nonadjusting" creditors are borrowed from Lucian A. Bebchuk \& Jesse M. Fried, The Uneasy Case for the Priority of Secured Claims in Bankruptcy, 105 YALE L.J. 857 (1996) [hereinafter Bebchuk \& Fried, Uneasy Case]. 
relative to foreign creditors. ${ }^{21}$ As long as the creditors understand the bankruptcy rules ex ante, however, they will be able to adjust the outof-bankruptcy rate of return that they demand. ${ }^{22}$

From the perspective of the debtor, however, the choice of regime is important even if all creditors adjust, because a reduction in the costs imposed by the bankruptcy system will reduce the overall cost of lending - leading to a reduction in the cost of capital for debtors. From the debtor's point of view, therefore, bankruptcy policy should be guided by the overall efficiency of the system. For these purposes, universalism offers the most appealing regime because it provides greater certainty with respect to the applicable rules, lower litigation costs, and a better system for reorganizations than does territorialism. $^{23}$

The current debate, therefore, focuses on three groups - adjusting creditors, who are indifferent to the choice of regime; debtors, who prefer universalism because it imposes lower costs; and nonadjusting creditors, whose role is examined in this Article. Unless nonadjusting creditors suffer losses under universalism that outweigh the efficiency benefits of that regime, territorialism must be rejected. To date, there has been no clear analysis of the impact of universalism on nonadjusting creditors, making it difficult to evaluate the claims in favor of territorialism. This Article provides the analysis required to evaluate those claims and, in the end, finds them wanting.

Part II of this Article defines what are termed "nonadjusting creditors," and explains why understanding the role of these actors is critical to understanding the debate on transnational bankruptcy. Part III presents a theoretical analysis and the impact of territorialism and universalism on nonadjusting creditors. Part IV examines the costs of each regime, and demonstrates that the costs of territorialism outweigh the costs of universalism.

\section{NONADJUSTING CREDITORS}

\section{A. Nonadjusting Creditors Defined}

The category of "nonadjusting creditors" includes any creditors that cannot, or will not, adjust the terms of their loans on a case-bycase basis in order to take into account the risks associated with the

21. On the other hand, the opposite will be true in other cases - that is, local creditors will enjoy an advantage ex post if the bankruptcy is local.

22. In fact, creditors may make adjustments to the rules in ways other than through the interest rate. They may, for example, alter the maturity of loans, alter the monitoring provisions, take more collateral, and so on. In the interests of simplicity and expositional ease, this Article will speak only of changes in the interest rate.

23. This claim may provoke objections from territorialists. In any case, this Article addresses the efficiency issue in Part III. 
loan, including the risk of nonpayment. Tort creditors, for example, enter into a creditor relationship with tortfeasors involuntarily and obviously do not adjust the terms of that relationship to reflect the risk that the debtor may not pay. The nonadjusting creditor category includes both involuntary creditors, such as taxation authorities and tort creditors, as well as voluntary creditors, such as trade creditors. ${ }^{24}$

The general category of nonadjusting creditors can be further divided into two subcategories, which I term "weakly nonadjusting" and "strongly nonadjusting." Both subcategories are nonadjusting in the sense that they are unable or unwilling to alter the terms of their loan based on the identity of the borrower. The creditors differ, however, in the extent to which they adjust credit terms over their entire portfolio of lending.

Nonadjusting creditors are termed weakly nonadjusting when they account for the risks they face by adjusting the terms of their loans on an expected value basis calculated over their entire portfolio of loans. For example, credit card companies are weakly nonadjusting creditors. A credit card company will charge a single interest rate to all of its cardholders, without differentiating one cardholder from another based on the risk of nonpayment. ${ }^{25}$ The company, however, will set its overall interest rate such that it earns, in expectation, a competitive rate of return. The weakly nonadjusting category might also include retail customers, trade creditors, employees, landlords, educational lenders, and health care providers. ${ }^{26}$ Each of these groups provides credit voluntarily, but typically does not adjust the terms of the credit on a debtor-by-debtor basis.

Most weakly nonadjusting creditors could, in principle, adjust each individual loan to take into account the risks presented by a particular debtor. Nevertheless, a creditor may rationally choose to remain nonadjusting because, for example, it is too costly to conduct a careful examination of each transaction and to structure appropriate terms for a specific loan. To assess the risk presented by a particular debtor, a creditor must consider the value of that debtor's assets, the amount of debt carried by the debtor, the relevant provisions of the applicable bankruptcy regime, and so on. Furthermore, even if the creditor collected this information, there would remain the cost of negotiating ap-

24. Although some voluntary creditors (including trade creditors) may be labeled nonadjusting, it should be kept in mind that they are likely to be at least partially adjusting. Such creditors may, for example, refuse to lend to debtors that are considered too much of a credit risk.

25. More sophisticated approaches exist, of course. The credit card company may decide to charge a different rate to different categories of cardholders, for example. Nevertheless, such creditors do not tailor the terms of their lending on a debtor-by-debtor basis.

26. See, e.g., John Hudson, The Case Against Secured Lending, 15 INT'L REv. L. \& ECON. 47, 56 (1995); Mark J. Roe, Commentary on "On the Nature of Bankruptcy: Bankruptcy, Priority, and Economics," 75 VA. L. REV.219, 225 (1989). 
propriate terms for a loan in light of the particularities of the debtor. In cases where these costs are relatively high and the amount of credit sought is relatively small, the creditor may find it more efficient to apply a single rate of interest to all its debtors. Again, credit card lending fits this description - it is simply too costly for a credit card company to assess the credit risk presented by each card holder, so the credit card company simply charges the same rate to each of them. ${ }^{27}$

In contrast to weakly nonadjusting creditors, strongly nonadjusting creditors extend credit on terms that fail to adjust even for the overall lending portfolio of the creditor. Tort creditors represent one example of this kind of lending. Tort creditors become creditors as a result of injury or accident without negotiation and without control of the terms of their lending. Tax obligations represent another possible example of a strongly nonadjusting creditor. ${ }^{28}$

This Article uses the terms adjusting and nonadjusting rather than the more commonly used terms "voluntary" and "involuntary" creditors $^{29}$ because the voluntariness of a transaction does not bear directly on the efficiency of the terms of the loan. The analysis in this Article turns on whether a creditor adjusts the terms of the loan for each debtor, not the willingness of the creditor to extend credit. Credit card companies, for example, are voluntary lenders, but do not adjust the terms of their lending on a transaction-by-transaction basis.

\section{B. Why Consider Nonadjusting Creditors?}

Nonadjusting creditors are important to the debate on transnational bankruptcy for two reasons. First, as discussed in Section III.A, nonadjusting creditors will behave inefficiently under a regime of universalism, potentially weakening the case for such a regime. Where creditors are fully adjusting, they select the lending terms of each transaction to yield a competitive return to the lender ex ante. Where creditors are nonadjusting, however, they do not tailor terms to the

27. See Bebchuk \& Fried, Uneasy Case, supra note 20, at 885; Lucian A. Bebchuk \& Jesse M. Fried, The Uneasy Case for the Priority of Secured Claims in Bankruptcy: Further Thoughts and a Reply to Critics, 82 CORNELL L. REV. 1279, 1300 (1997) [hereinafter Bebchuk \& Fried, Further Thoughts] ("[T]rade creditors generally charge uniform rates to all customers that are allowed to purchase on credit.").

28. The categorization of creditors as strongly nonadjusting rather than weakly nonadjusting is sometimes debatable. Tax and other government obligations, for example, may be considered weakly nonadjusting because the government is, at least in principle, able to adjust the terms of the loan and may be considered to do so over certain portfolios of lending. Tort creditors might also be more accurately considered to be weakly nonadjusting if courts permit the collection of an interest rate that resembles the risk-adjusted market rate. This article assumes that the tax authority and tort creditors are strongly nonadjusting. If it is assumed instead that they are weakly nonadjusting, the arguments advanced in this Article are stronger.

29. See, e.g., Lynn M. LoPucki, The Unsecured Creditor's Bargain, 80 VA. L. REV. 1887, passim (1994) [hereinafter LoPucki, The Unsecured Creditor's Bargain]. 
specific transaction. This leads to inaccurate borrowing decisions on the part of the debtor and, effectively, a subsidy paid from low-risk debtors to high-risk debtors. As a result, high-risk debtors will borrow too much (and, therefore, overinvest in their activity), and low-risk debtors will borrow too little (and underinvest in their activity). As shown in Section III.A, universalism may increase the variation in risk faced by lenders and, therefore, may increase the magnitude of this distortion.

Second, and perhaps more important, considering nonadjusting creditors serves an important pragmatic objective. Despite the nearunanimous support of the academic community, policymakers have chosen not to adopt universalism. Although a number of other arguments have been advanced for territorialism, ${ }^{30}$ its support leans heavily on a sense among judges, legislators, and some academics that territorialism can help small, local creditors. As a result, local creditors are often given protection ex post in the form of a refusal to turn local assets over to a foreign jurisdiction. Writing in 1944, Professor Nadelmann stated that "in most of the countries, delivery of local assets ... is refused at least if opposed by local creditors." 31 Those writing on the subject today demonstrate that little has changed. ${ }^{32}$ Thus, reluctance to adopt universalist policies is premised on a general view, one even shared by many supporters of universalism, that local creditors suffer losses when a country abandons territoriality. For example, Professor Westbrook, the most prominent contributor to the literature on transnational bankruptcies and a strong proponent of universalism, states:

The central argument for the Rough Wash is that a universalist rule will roughly even out benefits and losses for local creditors, who will gain enough from foreign deference to the local forum in one case to balance any loss from local deference to the forum in another... ${ }^{33}$

And in an accompanying footnote:

The bulk of countries most likely to join in transnational cooperation are those that believe that they are ... countries [in which the ratio of local

30. See generally LoPucki, Cooperation, supra note 2.

31. Kurt H. Nadelmann, International Bankruptcy Law: Its Present Status, 5 U. TORONTO L.J. 324, 339 (1944).

32. See Boshkoff, supra note 6, at 938 ("Cooperation is not valued as highly as the protection of American creditors."); see also Daniel M. Glosband \& Christopher T. Katucki, Claims and Priorities in Ancillary Proceedings Under Section 304, 17 BROOK. J. INT'L. L. 477,477 (1991) ("[C]ourts and commentators have struggled with the tension between protecting local claims in local bankruptcy proceedings and promoting international cooperation by ceding control of local assets to a foreign trustee."); Westbrook, Choice of Law, stlpra note 2, at 518 ("International cooperation will be achieved despite local prejudice only if policy makers are convinced... that over a run of cases local prejudice in some cases will be balanced by local gains in others.").

33. Westbrook, Theory and Pragmatism, supra note 2, at 465. 
assets to local claims is below the worldwide ratio] at least as often as they are ... countries [in which ratio of local assets to local claims is above the worldwide average]. Countries that think they will routinely be in surplus will not be very eager to join an international scheme; the benefits to be realized by everyone from greater realization on assets are probably too imprecise to persuade them that greater asset prices will outbalance loss of a consistent surplus position. ${ }^{34}$

United States courts have demonstrated a similar concern for the ex post treatment of local creditors and, as a result, a resistance to universalism. For example, in In re Toga Manufacturing, ${ }^{35}$ a Canadian company embroiled in bankruptcy proceedings in Canada filed a section 304 petition seeking an injunction against creditor action and turnover of U.S.-based assets. ${ }^{36}$ The court denied the petition, stating that the "[c]ourt must protect United States citizens' claims against foreign judgments inconsistent with this country's well-defined and accepted policies." ${ }^{37}$ Similarly, in Interpool Limited v. Certain Freights of $M / V$ Venture Star, ${ }^{38}$ the court asked whether "United States creditors will be similarly protected in both jurisdictions"39 and later in the opinion stated that "this Court does not intend to stand idly by while United States citizens and creditors are harmed."40 Rather than examining the debtor-creditor relationship from an ex ante perspective, these courts looked at the specific questions of law that affect the American creditor before the court and asked if that creditor would do as well under the foreign proceeding. ${ }^{41}$

34. Id. at $465 \mathrm{n} .26$; see also John D. Honsberger, Conflict of Laws and the Bankruptcy Reform Act of 1978, 30 CASE W. RES. L. REV. 631, 671-73 (1980) (stating that some may view a universal rule in the United States as a "giveaway" if American debtors do not receive similar treatment abroad); Gary Perlman, The Turnover of Assets Under Section 304 of the Bankruptcy Code, 12 FORDHAM INT'L L.J. 521, 531 (1989) (stating that courts that "emphasize the interests of U.S. creditors" are more likely to refuse turnover); Westbrook \& Trautman, supra note 4, at 657 ("The losses [a universalist country's] creditors would suffer in some cases would be balanced by gain in others.... It might [require reciprocity out of] fear $[$ that otherwise it would suffer greatly in a world of nations committed to the idea of territoriality."). But see Kraft \& Aranson, supra note 4, at 350 ("[C]reditors presumably know of the potential for bankruptcy and its attendant complications when they decide to do business with foreign companies.").

35. 28 B.R. 165 (Bankr. E.D. Mich. 1983).

36. Section 304 of the Bankruptcy Code permits a U.S. court to order, among other things, the turnover of a bankruptcy estate's property to a foreign jurisdiction. See 11 U.S.C. $\S 304$ (c).

37. In re Toga Mfg., 28 B.R. at 170.

38. 102 B.R. 373 (D.N.J. 1988).

39. Id. at 377.

40. Id. at 380. This Article argues, of course, that such ex post assessments of the welfare of local creditors do not lead to an overall increase in the well being of those creditors. See infra Part IV.

41. Not all American courts have been as resistant to the use of $\S 304$. There is a set of cases that grant $\S 304$ petitions fairly liberally. See, e.g., In re Gee, 53 B.R. 891 (Bankr. S.D.N.Y. 1985); In re Culmer, 25 B.R. 621 (Bankr. S.D.N.Y. 1982). 
Though not always understood by courts or commentators, concerns about the plight of local creditors under universalism are simply misplaced if all creditors can adjust the terms of their loans to reflect the risks they face. ${ }^{42}$ Contrary to the approach adopted by the courts cited above, a sound bankruptcy policy must take into account the fact that many creditors adjust the terms of their lending to account for their rights in bankruptcy. Because capital markets are competitive, adjusting creditors receive a competitive rate of return ex ante. If they stand to be denied recovery in the event of bankruptcy, they simply will charge a higher rate outside of bankruptcy. As a result, no sound reason exists to demand that they receive a particular return in bankruptcy. Put differently, attempts to "protect" local creditors by providing them with a higher recovery in bankruptcy simply lead to lower recoveries by such creditors outside of bankruptcy - the ex ante expected return remains unaffected. Recognizing the importance of adopting this ex ante perspective rather than the ex post perspective that dominates the literature is a critical step in understanding the advantages of universalism. ${ }^{43}$

Once the need for an ex ante perspective is understood, it becomes clear that concern for the welfare of local creditors matters only as applied to nonadjusting creditors, because adjusting creditors will take the existing regulations into account. ${ }^{44}$ The case for territorialism, therefore, relies heavily on the presence of nonadjusting creditors. Only if these creditors are somehow better off under territorialism can that regime be supported. In order to respond to the critics of universalism, therefore, we must consider the effect of universalism in the presence of nonadjusting creditors. If it turns out that concerns about nonadjusting creditors are misplaced, or if, as this Article argues, the costs generated by the presence of nonadjusting creditors are smaller in magnitude than the benefits of universalism, then the case for territorialism fails.

42. See Bebchuk \& Guzman, supra note 2, at 793-94; Rasmussen, supra note 2, at 35.

43. The importance of adopting an ex ante perspective is well recognized in the literature on domestic bankruptcies. See Barry E. Adler, A Re-examination of Near Bankruptcy Investment Incentives, 62 U. CHI. L. REV. 575 (1995); Lucian A. Bebchuk, The Effects of Chapter 11 and Debt Renegotiation on Ex Ante Corporate Decisions (HARVARD LAw SCHOOL PROGRAM IN LAW AND ECONOMICS DISCUSSION PAPER SERIES, No. 104, 1994); Robert K. Rasmussen, The Ex Ante Effects of Bankruptcy Reform on Investment Incentives, 72 WASH. U. L.Q. 1159 (1994). In the international bankruptcy literature, however, recognition has taken longer to arrive. See Bebchuk \& Guzman, supra note 2; Rasmussen, supra note 2.

44. From a more systemic perspective, we must also be concerned with the costs of adjustment by the adjusting creditors. These costs, however, will not affect the welfare of adjusting creditors because they are simply another factor to take into account when they adjust their terms. Put differently, the costs of adjustment will be passed on to the debtor. The impact of adjustment costs on our evaluation of territorialism and universalism is discussed in more detail below. See infra text accompanying note 88 . 


\section{ANALYSIS OF NONADJUSTING CREDITORS}

There is an existing debate about the most efficient way to treat nonadjusting creditors in the domestic sphere. ${ }^{45}$ This Article puts that debate to one side in order to focus on the international issues that arise in the presence of nonadjusting creditors. Specifically, this Article seeks to understand how to structure a choice of law rule when faced with a transnational bankruptcy. Because such a rule inevitably must select the applicable law from the affected domestic systems, the specific details of any single system cannot be determinative. Put another way, a rule that turns on choosing the regime with the "best" rules is impractical because there is no agreement on which rules are best. Thus, regardless of who is correct in the full priority debate in the domestic sphere, the analysis of this Article offers insight into how nonadjusting creditors should be treated in transnational cases.

\section{A. Weakly Nonadjusting Creditors}

This Section examines the impact of weakly nonadjusting creditors on transnational bankruptcy policy from an efficiency perspective. Although debtors of a weakly nonadjusting creditor may represent different levels of risk, the creditor will charge all such debtors a common rate of interest. ${ }^{46}$ This pooling of risk implies that debtors representing a relatively high level of risk for the creditor will be able to borrow based on terms that are more favorable than would be the case if the creditor were an adjusting creditor. Low-risk debtors, on the other hand, will face terms that are less favorable than what an adjusting creditor would offer. The low-risk debtors, therefore, subsidize the high-risk debtors, and this subsidy affects borrowing decisions.

Example. Imagine a trade creditor lending to two firms that represent identical credit risks, except for the fact that they are subject to different bankruptcy regimes. Suppose that under the regime applicable to Firm $A$, trade creditors recover as general unsecured creditors. On this assumption, the creditor can expect little or no recovery from Firm $A$ in the event of bankruptcy. ${ }^{47}$ Assume that the regime applicable to Firm $B$

45. The discussion of nonadjusting creditors in the domestic sphere takes place within the context of the debate regarding the desirability of granting secured debt priority over unsecured debt. The literature on this topic is voluminous. For a list of sources, see Bebchuk \& Fried, Further Thoughts, supra note 27, at 1281 n.5, 1283 n.11; Bebchuk \& Fried, Uneasy Case, supra note 20 , at 862 n.23, 865 n.27.

46. It is more accurate to say that debtors will be charged interest rates that do not fully reflect the idiosyncratic risk of their loans. It may be that a creditor adjusts the terms of its loans and manages to capture some of this risk. Such partial adjustment would not change any of the results.

47. It is well known that general unsecured creditors typically receive very little in bankruptcy. See infra note 71 . 
gives trade creditors the status of priority claimants in bankruptcy. ${ }^{48}$ The creditors' expected recovery, if Firm $B$ were to file for bankruptcy, may be substantial as a result of the priority status afforded to trade creditors. From the point of view of the creditor, therefore, Firm $A$ is a relatively high-risk debtor while Firm $B$ is relatively low-risk. ${ }^{49}$

Despite these differences, however, both Firm $A$ and Firm $B$ can borrow on the same terms. This arrangement clearly is inefficient because the borrowers are not paying the full cost of capital - there will be too much borrowing (and overinvestment) by the high-risk debtor and too little borrowing (and underinvestment) by the low-risk debtor. The lowrisk debtor (Firm $B$ ) will borrow less than it normally would because the terms of the credit are, in part, a subsidy of the high-risk debtor. The high-risk debtor (Firm $A$ ), on the other hand, will borrow more than it would if it had to internalize the full cost of its borrowing.

The magnitude of the inefficiency in lending by weakly nonadjusting creditors will depend on the range of risks they face when they make their loans. As the difference in risk between loans to the highand low-risk debtors grows, so does the magnitude of the associated distortion..$^{50}$ For the moment, assume that all non-bankruptcy related risks are the same for all loans. This allows the analysis to focus on the bankruptcy issues relevant to the current discussion. ${ }^{51}$ If, under this assumption, all loans represent roughly the same level of risk in bankruptcy, the outcome will be close to the efficient outcome - the rate charged on these loans will be close to the rate that an adjusting creditor would charge. In the extreme, if all loans receive the same treatment in bankruptcy, ${ }^{52}$ then, all else being equal, a fully adjusting creditor would charge all debtors the same interest rate - and that rate would be the same as the one charged by the nonadjusting creditor. If, on the other hand, the loans vary wildly in terms of risk, the nonadjusting creditor will nevertheless charge all debtors the same rate and, therefore, will lend less efficiently. Symmetrically, for individual debtors, as the interest rate charged by the nonadjusting credi-

48. Under U.S. law, this means that they would be entitled to priority under section 507 of the Bankruptcy Code.

49. Because the firms are assumed to be identical except for the applicable bankruptcy law, the designations high- and low-risk refer only to the bankruptcy risk facing the creditor.

50. Formally, as the variance in the distribution of risk faced by the creditor grows, so does the magnitude of the associated distortion.

51. The impact of territorialism on other risks will be discussed infra where it is shown that one of the costs of territoriality is that it increases the risks that creditors must take in making loans. See infra Section III.A.

52. This is the case for purely domestic lending because the same bankruptcy rules apply regardless of the identity of the debtor. Recall that we have assumed that all debtors are identical in order to isolate the effect of the bankruptcy rules. 
tor moves further from the interest rate that an adjusting creditor would charge, the distortionary effect on borrowing decisions grows. ${ }^{53}$

Notice that, despite the presence of this distortion, weakly nonadjusting creditors are not "cheated" in any way. That is, over their full portfolio of loans, they receive an expected return that is adjusted for the overall risk they face. ${ }^{54}$ Because these creditors receive, on average, a market return, our choice of law objective is simply to enhance the efficiency of this lending - the benefits from which are enjoyed by the debtor. From an efficiency perspective, therefore, an optimal choice of law rule seeks to reduce the variation in risk faced by a given creditor. Reducing the variance of a creditor's expected return in the event of bankruptcy reduces the size of the distortion created by the existence of weakly nonadjusting creditors, and thereby reduces the subsidy provided by low-risk debtors to high-risk debtors. If we can ensure that the creditor faces a single bankruptcy regime, and thus a single set of bankruptcy risks, the amount of lending and borrowing will be closer to the efficient level than if the applicable bankruptcy regime varies according to the identity of the debtor.

Under territorialism, a creditor can seek recovery from local assets under local bankruptcy rules. Assuming that sufficient assets are available, the creditor need not consider the application of any other bankruptcy law. In this sense, the lending of that creditor is governed by a single bankruptcy regime. ${ }^{55}$ Under universalism, a creditor's recovery in bankruptcy depends on the substantive rules of bankruptcy - in particular the priority scheme - of the debtor's jurisdiction. ${ }^{56}$

53. Notice, however, that the cost of being a low-risk borrower with a nonadjusting creditor limits the magnitude of the distortion. As the difference in risk presented by the low-risk debtor as compared to the high-risk debtors grows, the subsidy paid by low-risk debtors to high-risk debtors grows. This eventually will cause some low-risk debtors to seek alternative financing rather than pay the implicit subsidy. This will, of course, limit the range of risks facing the creditor, and thus limit the distortion of lending markets.

54. The fact that these creditors are not cheated allows us to dismiss many of the concerns commentators have expressed about the problems creditors will face if they cannot adjust on a debtor-by-debtor basis. As a result, we can focus more directly on the overall efficiency of the system. See, e.g., LoPucki, Cooperation, supra note 2, at 712 ("[A] trade creditor rarely would find it cost-effective to discover the home countries of its corporate customers, let alone to evaluate the insolvency regimes of those countries and to adjust the credit terms accordingly."); Westbrook, Choice of Law, supra note 2, at 534 ("There would be real difficulty applying Hong Kong preference law to a small United States supplier.").

55. In many cases, of course, local assets will not be available and the creditor will have to file a claim abroad under a foreign law. For the moment, we ignore this possibility in order to make the strongest possible statement in favor of territoriality. See infra Section IV.B.3, where the possibility that more than one bankruptcy law applies to the creditor under territoriality is considered.

56. This Article focuses on the priority systems of bankruptcy regimes because the recovery for nonadjusting creditors, who are typically unsecured, depends primarily on whether or not they are granted priority status. If they recovery as a general unsecured creditor (as opposed to a priority claimant) in a liquidation, the expected recovery is almost zero. See LoPucki, The Unsecured Creditor's Bargain, supra note 29, at 1932-33 \& nn.172-73 ("[S]ecurity tends to expand to the liquidation value of the collateral as a debtor sinks into 
Because a single creditor may lend to debtors from several different countries, ${ }^{57}$ the bankruptcy risk faced by the creditor will depend on the identity of the debtor in a particular case. For a nonadjusting creditor, therefore, universalism aggravates the distortion discussed above in a way that territorialism does not. Note how this affects the lending of nonadjusting creditors. In addition to whatever other factors affect the expected return on a loan (for example, interest rate, financial status of the debtor, maturity date, and so on), the priority rules in the various jurisdictions are relevant. A particular loan, therefore, will represent a higher risk if the main jurisdiction (for bankruptcy purposes) provides a low priority for the creditor. It will represent a lower risk if the main jurisdiction grants the creditor a high priority. In other words, as a result of the differences among bankruptcy rules, universalism increases the variance of the risks faced by the creditor, increases the size of the distortion in lending, and reduces the efficiency of lending by weakly nonadjusting creditors.

Example. Imagine a nonadjusting creditor with two debtors. ${ }^{58}$ Both debtor $A$ and the creditor are from country $A$ and debtor $B$ is from country $B .{ }^{59}$ The loans are made in country $A$. Other than their country of origin, the two debtors are identical. Assume that under the domestic bankruptcy law of country $A$, the creditor would not be a priority claimant and, therefore, would share pro-rata with other unsecured creditors. Under the laws of country $B$, however, the creditor would receive priority and would be paid first, ahead of all other unsecured claimants.

If the creditor were an adjusting creditor, it would take into account the different bankruptcy rules it faces and would charge rates that account for the treatment it would receive in bankruptcy. For concreteness, suppose that an adjusting creditor would charge $12 \%$ for a loan to the debtors if that loan were governed by the laws of country $A$, but would demand only $8 \%$ if country $B$ 's law governed.

Because the creditor being considered is not, on average, "cheated," it must receive the same average return as an adjusting creditor. In our example, therefore, the nonadjusting creditor will charge $10 \%{ }^{60}$ Because the debtor from country $A$ gets credit at $10 \%$ rather than the $12 \%$ that an adjusting creditor would charge, it will borrow more than it would

financial distress."). In fact, it is only when a firm seeks to reorganize that unsecured creditors are promised significant payment. See id. at 1932 n.172. Reorganization is facilitated by universalism rather than territorialism - implying that unsecureds are likely to do better under universalism.

57. Or, under a menu approach, to debtors who have selected a variety of regimes.

58. The number of debtors could, of course, be increased to any number. I choose two only for simplicity.

59. For the purposes of this example, a debtor that is "from" a country will have its main bankruptcy proceedings administered by that country.

60 . The $10 \%$ figure assumes that the loans are equal in size. 
from an adjusting creditor. ${ }^{61}$ The benefits enjoyed by this debtor will be subsidized by the debtor from country $B$ who is charged $10 \%$ rather than $8 \% .^{62}$ This debtor will borrow less than it would in an efficient market. ${ }^{63}$

In this example, we see that the creditor lends inefficiently because his recovery in bankruptcy depends on the choice of substantive bankruptcy law. As an efficiency matter, therefore, this Section has shown that universalism distorts lending markets in a way that territorialism does not. Specifically, universalism causes relatively low-risk debtors to subsidize relatively high-risk debtors. In Section IV.A.1, this Article considers how large this distortion is likely to be.

\section{B. Strongly Nonadjusting Creditors}

Having discussed the way in which the conventional universalist approach affects weakly nonadjusting creditors, I now turn to strongly nonadjusting creditors. By assumption, strongly nonadjusting creditors fail to adjust the terms of their lending to reflect the likelihood of recovery in bankruptcy. They adjust neither on a case-by-case basis, nor over their entire portfolio of loans. There is no reason to think, therefore, that changing the treatment given to these creditors in the event of bankruptcy will affect their behavior. Consider, for example, a tort creditor. Because she does not negotiate the terms of her extension of credit to the tortfeasor, the tort victim cannot adjust the terms of her lending. Law, not contract, determines those terms. Tort victims and other strongly nonadjusting creditors, therefore, simply extend credit based on terms that are determined without adjustment for the return the creditor will receive, either with respect to a particular loan or over a portfolio of loans. A system designed to give these creditors the opportunity to recover under local rules would, there-

61. A debtor borrowing up to the point at which the marginal cost of borrowing equals the marginal benefit of borrowing will obviously borrow more at a rate of $10 \%$ than it would at a rate of $12 \%$.

62. In a fully competitive market, this result could not hold in equilibrium. The debtor being overcharged for credit (debtor $B$ ) would simply turn to a different source, making all creditors fully adjusting. In the context of nonadjusting creditors, however, markets will often be sufficiently illiquid that one debtor can subsidize another. For example, trade creditors may not find it worthwhile to adjust their loans on a case-by-case basis. The credit extended by these creditors is associated with the sale of goods or services to the debtor. It may not be possible for the debtor to acquire the goods or services with more finely tuned credit terms. In this situation, the debtor simply will have to accept the higher rate, even though it includes a subsidy to debtor $A$. But see supra note 24 (discussing how creditors might achieve partial adjustment in a transnational setting).

63. In a more complete model of the borrowing process, the rate would have to adjust to account for the fact that one debtor is borrowing more than the other. This effect is ignored for simplicity. Even if the effect were accounted for, however, it would remain the case that either one debtor would subsidize the other, or only one of the debtors would borrow from the creditor. 
fore, yield no efficiency gains. Strongly nonadjusting creditors will behave in the same fashion regardless of the bankruptcy rule. ${ }^{64}$

There remain only two possible sources of concern regarding strongly nonadjusting creditors. First, a form of fairness argument might arise, premised on the notion that these creditors somehow are entitled to recover under local law. To the extent that this argument relies on the frustrated expectations of the strongly nonadjusting creditors, it lacks force because the creditors at issue have, by definition, not relied on local law. The fact that they do not adjust implies that their lending behavior is unaffected by the expected rate of return on their lending. As long as the bankruptcy proceedings of the home country are fair, and as long as these creditors can pursue their claims under the laws of the home country, there is no reason not to adopt universalism with respect to these creditors. Most importantly, the treatment of strongly nonadjusting creditors should not be allowed to undermine the increased total recovery and greater fairness generated by universalism. Second, it may be argued that strongly nonadjusting creditors will find it difficult to litigate their claim in a distant forum. To the extent this is true, procedures could be established to appoint a representative who could file claims on behalf of groups of such creditors. $^{65}$ For example, a representative could represent all employees in a case. Such an approach would reduce the costs imposed on these creditors. Indeed, if we truly want to reduce the costs facing these

64. It might be argued that a tort victim can adjust her level of care in response to the compensation scheme that is in place. Specifically, the potential tort victim's level of care will depend on the expected compensation in the event of an accident. Because only one level of care can be selected, it will not be appropriate with respect to all tortfeasors. To the extent that there is divergence between the chosen level of care and the level of care that would be chosen based on an individual potential tortfeasor, an inefficiency is generated. By providing local bankruptcy priority, the argument goes, we reduce the variance in expected returns for this creditor in much the same way that we reduce the variance in returns to weakly adjusting creditors. The magnitudes at issue here, however, are almost certainly very small. It is unlikely that a potential tort victim would change her behavior significantly based on the choice of law rules for transnational bankruptcy. First, because she is only probabilistically a tort victim, the rules' impact on her will be only a fraction of their impact on other creditors. Second, because she does not know the identity of a possible future tortfeasor, her conduct will be based on a weighted average of her expected returns under the various possible regimes. If one is injured in the United States, the tortfeasor will very likely be American - implying that the dominant factor in the potential victim's calculation will be American law. Other legal systems will have an impact, but only a small one. Furthermore, the truly important variable for determining the standard of care is the size of the damage award. When the tort occurs in the United States, the damage award will be determined by applying the substantive law of the United States. Only then will the relevant bankruptcy regime determine priority. A much larger source of variance than the choice of bankruptcy law will be the specifics of the tort - making the choice of bankruptcy law a concern of lower order.

65. The European Union Convention on Bankruptcy, for example, permits the liquidator in an insolvency proceeding in one EU country to file claims on behalf of all creditors in that proceeding in other EU proceedings involving the same debtor. See Jay Lawrence Westbrook, Universal Priorities, 33 TEX. INT'L LJ. 27, 30 (1998) [hereinafter Westbrook, Universal Properties]. 
creditors, we could achieve this result without altering the priority scheme of the main jurisdiction by having the costs of nonadjusting creditors (whether individually or collectively) paid by their own governments or out of the estate.

\section{COMPARING UNIVERSALISM AND TERRITORIALISM}

This Part demonstrates that, although the theory presented in Part III shows that the costs of universalism are higher in the presence of nonadjusting creditors, these costs are probably quite small. As a result, the costs of eliminating the distortion caused by nonadjusting creditors almost certainly exceed the benefits of doing so. After considering the magnitude of the identified distortion, this Part examines the costs of correcting the problem. Ultimately, the conclusions of this Part provide further evidence in support of universalism. Indeed, they demonstrate that even deviations from universalism advocated by commentators who favor that approach impose costs that outweigh their benefits. ${ }^{6}$

\section{A. The Costs of Universalism}

\section{The Magnitude of the Distortion}

To appreciate the amounts at stake, consider first the impact of the distortion on the lending terms of weakly nonadjusting creditors, assuming that the amount recovered in the event of the debtor's failure depends on the choice of bankruptcy law. When setting the terms for its portfolio of loans, one would expect a weakly nonadjusting creditor to consider a host of factors that have nothing to do with the relevant bankruptcy regime. These would include the characteristics of the pool of debtors; alternative uses for the funds; the out-of-bankruptcy collection system available to the creditor; the likelihood of bankruptcy; the number and priority of other creditors; the total amount of outstanding debt; the likelihood that the debtors will acquire future debt; the likelihood that legal claims are currently pending or will arise in the future, ${ }^{67}$ and the ability to enforce a judgment against a foreign debtor.

66. For example, Trautman et al. suggest that they are prepared to accept some deviation from universalism: "If cases should arise where the reasonable expectations of unsophisticated creditors (in the United States, 'the little old lady in tennis shoes') might suffer unfairly, there is no reason a special rule cannot be applied in such cases." See Trautman et al., supra note 6, at 624. In fact, this Section argues that there are good reasons to avoid such special rules.

67. In In re Johns Mansville Corp., 36 B.R. 727 (Bankr. S.D.N.Y. 1984), the debtor, Johns Mansville was forced to file for bankruptcy because it was unable to obtain credit the potential lenders were concerned that the future tort claims against Johns Mansville would be so large that their loans would not be repaid. See Alan N. Resnick, Bankruptcy as 
The above factors will be the most important in setting the terms of a nonadjusting creditor's lending because they directly affect the creditor's return. In contrast, the choice of bankruptcy regime has a much more indirect effect on the creditor's return. A change in the choice of law regime only affects a particular loan if (i) the debtor is foreign; (ii) the bankruptcy laws of the countries involved differ with respect to the particular creditor; and (iii) the value of assets is such that the difference in the laws translates into a difference in return. Because the bankruptcy rules impact the creditor's return indirectly, we would expect a change in the choice of bankruptcy regime to have only a marginal effect on the terms offered by the creditor negotiating in the shadow of the law. ${ }^{68}$ The choice of territorialism as compared to universalism, therefore, will have only a small effect on the expected return of the creditor. This implies that factors unrelated to the bankruptcy choice of law will be the primary determinants of the variance in returns faced by a particular creditor. Whatever inefficiency this variance creates, therefore, will not be sensitive to changes in the choice of law system.

\section{The Amount at Stake}

Consider the dollar amounts at stake. Compared to the total amounts involved in a bankruptcy, these are likely to be quite small. Nonadjusting creditors may hold a significant share of the claims against the bankruptcy estate, but a change in choice of law rules will affect only a small share of those claims. Thus, for our purposes, we need focus only on loans that nonadjusting creditors hold and that will receive different treatment under the two systems (universalism versus territorialism).

We are, therefore, not concerned with loans held by secured creditors or other adjusting creditors. Similarly, the distortion discussed here will not affect loans held by nonadjusting creditors who are not priority claimants. ${ }^{69}$ Such creditors will collect on the same basis pro rata with other creditors - regardless of the choice of law rule. Furthermore, these creditors typically receive no recovery in bankruptcy, making the choice of law rule irrelevant. ${ }^{70}$ Finally, some prior-

a Vehicle for Resolving Enterprise-Threatening Mass Tort Liability, 148 U. PA. L. REV. 2045, 2046 (2000).

68. That is, one would expect the terms to be relatively inelastic with respect to the choice of law rule.

69. That is, those who do not have a priority under the bankruptcy laws of the home country or under local law.

70. See Domenic E. Herbert \& Michael J. Pacitti, Down and Out in Richmond, Virginia: The Distribution of Assets in Chapter 7 Bankruptcy Proceedings Closed in 1984-1987, 22 RICHMOND L. REV. 303, 315-16 (1988). 
ity creditors will receive priority under either choice of law rule. These creditors face similar prospects for recovery under either rule. ${ }^{71}$

Ultimately, the only group of nonadjusting creditors whose expected return is significantly affected by the choice of law rule consists of those creditors that will receive priority under one choice of law rule and not under another. When a firm whose home country is abroad ends up in bankruptcy, local nonadjusting creditors will prefer territorialism if local law gives them priority, while foreign law does not. On the other hand, they will prefer universalism when local law does not provide a priority but foreign law does.

\section{Employees and Trade Creditors}

The above discussion demonstrates that the group of weakly nonadjusting creditors who are likely to benefit from territorialism represents a small percentage of all creditors. Should the efficiency of the bankruptcy process be compromised for the majority of creditors in order to assist this minority? Proponents of territorialism advocate precisely this trade-off. Rather than consider the impact of territorialism on all creditors, however, attention is often drawn to a small number of creditors that seem to elicit sympathy from commentators. In order to address the arguments of territorialists as directly as possible, therefore, this Article now turns to consider those same creditors. It is important to keep in mind, however, that they represent only a small fraction of the total value at stake in a bankruptcy, and that adopting territorialism to assist these creditors will impose a cost on the entire system - ultimately leading to a higher cost of lending.

The weakly nonadjusting creditors that seem to attract the attention of courts and commentators critical of universalism are employees and trade creditors. These creditors, however, present a concern only to the extent that they face different outcomes under universalism than under territoriality. ${ }^{72}$ Although one can imagine cases in which the choice of law regime may matter for these claimants, it often will not. Admittedly, differences exist in the way bankruptcy regimes treat claims of employees, and, to a lesser degree, trade creditors. It is im-

71. Strictly speaking, the likelihood of recovery for such creditors under territorialism will be a function of local assets and other local priority obligation whereas under universalism it will be determined by worldwide assets and other priority obligation throughout the world. This might lead to different outcomes under the different regimes. Recovery may also depend on the ordering among priority claimants, in which case the choice of law may have some effect.

72. For example, under Mexican law, employees receive super-priority (including priority over secured creditors) for unpaid wages earned within one year of the filing for bankruptcy. See Rasmussen, supra note 2, at $14 \mathrm{n} .59$ (citing "Ley de Quiebras y de Suspension de Pagos," D.O., 1993 art. 261). Under American law, employees do not receive super-priority and their recovery as priority claimants is limited to $\$ 4,000$, which must have been earned within 90 days of the bankruptcy filing. See 11 U.S.C. $\$ 507(3)$. 
portant, however, not to exaggerate these differences. ${ }^{73}$ A complete comparison of the many national priority schemes lies outside the scope of this Article, but a cursory look at a few helps to understand the differences and similarities among them.

First, national systems rarely provide priority status to unsecured trade creditors. None of the countries surveyed for this Article provides such a priority, ${ }^{74}$ with the exception of France (which provides priority to only a limited number of trade creditors ${ }^{75}$ ) and Mexico. ${ }^{76}$ For a trade creditor, therefore, the filing of bankruptcy by the firm probably signals the end of its ability to collect regardless of the applicable choice of law regime. ${ }^{77}$ In other words, arguments that universalism is unduly harsh on trade creditors ${ }^{78}$ or that trade creditors are subject to the distortion explained in this Article, miss the mark. In the vast majority of cases, the choice of law rule in bankruptcy will have no impact on trade creditors because they do not recover anything in either case.

The treatment of employees presents a more complex problem. A basic similarity exists among the various systems, in that every country surveyed provides at least some priority status for the claims of employees. ${ }^{79}$ Within the category of priority claimants, however, the

73. "[T]he great majority of systems give high priority to the claims of employees and of public entities, especially revenue authorities." Westbrook, Choice of Law, supra note 2, at 511. "These national [priority] systems differ, although they also have some important commonalities. For example, our country is alone, as far as I know, in granting special protection to consumers who have made deposits with retail stores and landlords. On the other hand, we have in common with many other countries priority systems favoring employees, the domestic fisc, and secured creditors." Westbrook, Universal Priorities, supra note 65, at 30 .

74. The following countries' bankruptcy regimes were considered: United States, Canada, Mexico, Argentina, Brazil, Egypt, France, Germany, Israel, Japan, Netherlands, Switzerland, and England.

75. See 1 INTERNATIONAL LOAN WORKOUTS AND BANKRUPTCIES, supra note 6, at 353.

76. See Am. LaW InST., TRanSNational InsolvenCy PROJECT, International STATEMENT OF MEXICAN BANKRUPTCY LAW 69-71 (Tent. Draft Apr. 15, 1998).

77. This assumes that the firm is to be liquidated. If the firm is to be reorganized, there is little doubt that the more efficient regime is universalism. See infra text accompanying note 98 .

78. This argument is difficult to support on its own terms because trade creditors are almost certainly weakly nonadjusting and, therefore, will receive a market rate of return over their portfolio of lending. Given this fact, it is difficult to know what it means for the system to be "unduly harsh." Nevertheless, this claim is addressed because the fairness of universalism is an oft-cited concern.

79. See INTERNATIONAL LOAN WORKOUTS AND BANKRUPTCIES, stupra note 6, at 13137 (Argentina), 171-72 (Brazil), 269-70 (Egypt), 302-53 (France), 377-78 (Germany), 423-24 (Israel), 499-500 (Japan), 566 (Netherlands), 592-93 (Switzerland); J.H. DALHUISEN, DALHUISEN ON INTERNATIONAL INSOLVENCY AND BANKRUPTCY \$ 1.06(1) (1986) (England); AMERICAN LAW INST., TRANSNATIONAL INSOLVENCY PROJECT, INTERNATIONAL STATEMENT OF CANADIAN BANKRUPTCY LAW (Tent. Draft, Apr. 15, 1997) (Canada); 11 U.S.C. $\$ 507$ (1994) (United States); INTERNATIONAL STATEMENT OF MEXICAN 
status of employees' claims, and the amount of those claims, vary from country to country. For example, in the United States, employees' claims rank behind only secured claims, administrative expenses, and claims allowed under section 502(f) of the Bankruptcy Code. ${ }^{80}$ The amount of employees' claims that are subject to this priority, however, is limited to $\$ 4,000$ for each individual or corporation for wages and salaries. There is also a provision for employee benefit plans, but it is limited to "the number of employees covered by each such plan multiplied by $\$ 4,000$," minus the amounts paid to the covered employees under the wage priority. ${ }^{81}$ In contrast, Mexican employees receive a "super-priority" - recovering ahead of most secured creditors as well as other unsecured creditors. Furthermore, it does not appear that their potential recovery is capped. ${ }^{82}$

The above juxtaposition of the United States and Mexico, however, is somewhat misleading. Most major countries have comparable, though not identical, provisions for the priority status of employees. Under the laws of the United States, Canada, Germany, Israel, Australia, Switzerland, England, and Egypt, employees receive priority behind secured claims and administrative expenses. In Japan, the Netherlands, and Argentina the same is true, although employees also recover behind at least one tax authority. ${ }^{83}$ The priority accorded employees' claims, therefore, although not completely identical, seems broadly consistent across regimes. Somewhat more variation appears in the amount of an employee's claim that is entitled to priority status. In the United States, as mentioned above, this is limited to $\$ 4,000$. In Canada, it is limited to $\$ 2,000$. Several other countries give no apparent cap on the size of such claims, while other regimes, such as Germany's, limit priority to claims for wages and benefits earned within a specified period of time.

The importance of differences in the size of an allowable claim, however, is muted by the nature of employment contracts. Employees typically receive payment on a regular basis - biweekly or monthly, for example. It is difficult for a firm - especially a large multinational firm - to continue to function if it suspends payments to its employees for more than a couple of pay periods. With the possible excep-

BANKRUPTCY LAw, supra note 76 (Mexico); Section 556, Corporations (New South Wales) Act 1990 (this is a state statute but the laws of other states within Australia are identical); see also MULTINATIONAL COMMERCIAL INSOLVENCY B-1 (1993).

80. Section 502(f) claims are those that arise in the ordinary course of the debtor's business after the commencement of an involuntary bankruptcy proceeding but before the appointment of a trustee or the order of relief. See 11 U.S.C. § 502(f) (1994). The complete list of priorities under U.S. law is provided in 11 U.S.C. $\S 507$ (1994).

81. 11 U.S.C. $\$ 507(\mathrm{a})(4)$.

82. See AM. LAw INST., supra note 76, at 71.

83. The remaining country surveyed, Brazil, provides a super-priority for employees' claims that is subordinate to a super-priority for on-the-job-accident claims. 
tion of insiders, employees are unlikely to continue working if they are not paid. As a result, the employee wage claims that exist in bankruptcy will typically represent a small amount of money per employee and will typically cover a short period of time. The actual difference between, for example, the open-ended Australian priority (which has no cap on wage claims) and the restricted American priority for employees, therefore, will be much less in practice than it appears from the bankruptcy statutes. ${ }^{84}$

Even if the treatment of employees varies from one jurisdiction to another, addressing the costs of that variance by adopting territorialism simply introduces another cost that will drive up the out-ofbankruptcy costs of the credit extended by labor. Specifically, as elaborated in Section IV.B.4, territorialism undermines the ability of a firm to reorganize. 85 A bankrupt firm with obligations to its employees often will pay the employees' claims in its proposed plan of reorganization. Firms do this to keep the employees they will need for a successful reorganization and to maintain employee morale. Because reorganization is much easier under universalism than under territorialism, employees can, therefore, expect a higher recovery in bankruptcy under universalism than under territorialism. ${ }^{86}$

\section{Creditor Behavior to Reduce the Costs of Universalism}

Finally, if universalism imposes a significant cost on transactions, creditors can adapt their behavior to reduce those costs. It generally will not be costly for a weakly nonadjusting creditor to acquire enough information to adjust its loan - at least partially - in order to take into account the relevant bankruptcy regime. In other words, a weakly nonadjusting creditor may become an adjusting or partially adjusting creditor in order to reduce the costs of universalism. For example, imagine a trade creditor that lends to a variety of automobile producers. Suppose further that the trade creditor's recovery in bankruptcy depends on the applicable law. ${ }^{87}$ The relevant universe of possible laws might include those of the United States, Japan, and Germany. Although it may be too costly for the creditor to adjust its loans for each of the many small transactions the creditor undertakes,

84. This argument, of course, is less applicable to differences in the treatment of other employee claims, such as claims for unpaid benefits.

85. See infra text accompanying notes $96-99$ (discussing the importance of reorganization and the problem it presents for territorialism).

86. In addition, the greater likelihood of reorganization is valuable to employees because it makes it more likely that they will be able to keep their jobs after the bankruptcy allowing them to avoid the dislocation costs associated with searching for new employment.

87. This assumption is probably false, see supra Section IV.A.2, but is made for expositional convenience. 
the cost of making adjustments to account for the country of origin of the debtor would be small. That is, it would cost the creditor very little to investigate the bankruptcy laws of each of the three relevant jurisdictions and modify its lending arrangements based on the home country of the debtor. Note that the creditor would need to undertake this inquiry only once, and it could apply the resulting adjustment to all subsequent transactions. The cost of the inquiry, therefore, can be amortized over many transactions. Alternatively, individual creditors could specialize by country and thereby price their loans more accurately. These adjustments would not require customizing each transaction, but rather would simply require a small expansion of the "menu" of standard transactions to account for the home country of the debtor. If the low cost of making this adjustment still exceeds the benefits, this simply implies that the overall costs of universalism are small.

\section{B. The Costs of Territorialism}

This Section highlights the costs of territorialism that are most important to our discussion of nonadjusting creditors. It does not, by any means, present a complete discussion of the costs of territorialism, but it suffices to demonstrate that these costs outweigh those of universalism. $^{88}$

\section{Informational Needs of Adjusting Creditors}

The first point to note is that territoriality dramatically increases the transaction costs faced by adjusting creditors. Imagine, for example, a fully adjusting creditor that lends in an unsecured fashion to a debtor. In order to adjust the terms of its lending, this creditor must investigate a variety of facts, including the size and priority of other outstanding debts. Under universalism, the creditor can restrict this inquiry to the law of one country (the debtor's home country), and then only needs to identify the current and likely future borrowing of the debtor and the value of assets likely to be available in bankruptcy to satisfy creditors.

Under territorialism, the creditor's informational needs, and therefore its transaction costs, are much greater. The creditor must acquire all the information it would need under universalism, and, in addition needs to know the current location of assets, the likelihood that they

88. A more complete list of the costs of territorialism might include the administrative cost of administering multiple bankruptcies; the cost of multiple bankruptcies on creditors that must pursue their claims in many jurisdictions at the same time; and the costs of a race to the courthouse. Once bankruptcy is filed in one jurisdiction, creditors will race to attach the assets in jurisdictions in which bankruptcy has not yet been filed and that, therefore, are not subject to an automatic stay. 
will be moved as well as the location to which they might be moved, the applicable law in every country in which there are assets or into which assets may be moved in the future, and the creditor's priority under the bankruptcy laws of each of these jurisdictions. The following example demonstrates the difficulties facing an adjusting creditor under territorialism.

Example. Suppose that there are $N$ countries in which assets are currently located and there exists $M$ other creditors. For simplicity, we ignore the possibility that the assets may be moved prior to bankruptcy or that there may be future borrowing - considerations that would further increase the amount of information required under territorialism. Under universalism, the creditor only needs to identify two pieces of information - the value of the assets and its priority under the laws of the home country. Under territorialism, however the creditor needs to identify the value of assets in every country, the nationality of all other creditors, ${ }^{89}$ and its priority in each country - a total of $2 N+M$ pieces of information.

The extent to which turnover of assets is allowed may also depend on the country to which the assets would be delivered - country $A$ may allow turnover to country $B$, but not to country $C .^{90}$ In this latter case, the creditor will require information about each country with respect to every other country, plus information on the nationality of other creditors and the value of assets in each country - a total of $N^{2}+N+M$ pieces of information.

\section{The Cost of Information}

Furthermore, the costs of collecting each piece of information is greater under territorialism than it is under universalism. For example, under territorialism the applicable laws in country $A$ may depend on whether or not there has already been a bankruptcy filing in country $B$, and whether or not a distribution has taken place. ${ }^{11}$ Similarly, much of the information required under territorialism, but not under universalism, is very costly. For example, it is difficult enough to determine the total assets of a firm, but it is much harder to identify the location of all those assets because financial documents may not include locational information. Indeed, in some cases, the information required under territorialism is not merely harder to accumulate - it is unavailable. For instance, a creditor can almost never know with

89. The nationality of other creditors is important because territorialism schemes often favor local creditors over foreign creditors.

90. For example, the United Kingdom provides for some flexibility on the part of courts when there are certain "established arrangements" in place between the U.K. and the foreign jurisdiction. No such arrangements exist with the United States. See Ian F. Fletcher, Commentary on Boshkoff: Some Gloomy Thoughts Concerning Cross-Border Insolvencies, 72 WASH. U. L.Q. 943, 943-44 (1994).

91. For example, under the U.S. Bankruptcy Code, payment in a foreign proceeding must be taken into account in an American distribution. See 11 U.S.C. $\$$ 508(a) (1994). 
certainty whether or not collateral will be moved from one jurisdiction to another in the future, ${ }^{92}$ particularly with easily moveable collateral, including financial collateral. ${ }^{93}$

The most direct consequence associated with the increase in informational costs will be an increase in the cost of borrowing faced by the debtor as creditors pass on their higher costs.

\section{The Number of Nonadjusting Creditors}

The increase in costs imposed on creditors (and passed on to debtors) will also alter the behavior of creditors, driving some of them to become weakly nonadjusting. The following example serves to demonstrate how this can occur.

Example. Imagine that a creditor wishes to lend to two identical firms and plans to adjust its loan to account for the risks associated with each. Suppose that a territorialist regime is in place and that each debtor has a $50 \%$ chance of moving its assets to a separate jurisdiction with bankruptcy rules that are less favorable to the creditor. At the time of the loan, the creditor cannot identify whether a debtor will move its assets, and so the creditor must charge a rate that is a weighted average of the rate it would charge if it knew the assets would be moved and the rate it would charge if it knew they would not be moved. In this sense, the creditor can only adjust partially. Thus, if one of the debtors moves its assets to the foreign jurisdiction, the debtor that has not moved its assets (the low-risk debtor) will be subsidizing the borrowing of the debtor who moved (the high-risk debtor). ${ }^{94}$ The formerly adjusting creditor, therefore, would face the same distortion that is faced by nonadjusting creditors under universalism.

92. Although creditors can prevent the movement of collateral from one jurisdiction to another by contract, this solution generates significant costs. First, it limits the flexibility of investment decisions by reducing the mobility of capital. If the bulk of a firm's valuable assets are unable to change jurisdictions, the firm is less able to respond to opportunities, and may be unable to pursue certain high value projects. This problem is especially severe in the case of financial assets because the assets are much more valuable to the firm if they can be used to cover expenses. If those expenses are subject to the approval of the creditor, there will be severe hold-up problems. See Bebchuk \& Guzman, supra note 2, at 800-02 (discussing the inability of private contracting to eliminate the costs of territorialism). The fact that contractual conditions of this sort exist; see LoPucki, Cooperation, supra note 2, at 758-59, does not contradict the claim that such provisions carry costs because the existing system is a territorialist one. The existence of such contracts merely suggests that, where they are present, they impose a lower cost than the risk that the collateral may be moved. In other words, it demonstrates the relative size of the two different costs imposed by territorialism but it is not evidence of the size of either of these costs compared to what would exist under universalism.

93. "In some cases the principal assets will be either mobile or outside the boundaries of any country." LoPucki, Cooperation, supra note 2, at 716 (quoting In re Rimsat, Ltd., 98 F.3d 956, 961-62 (7th Cir. 1996).

94. See supra note 92. 
Thus, although territorialism reduces the magnitude of the distortion discussed in Part III, it also increases the number of creditors that face a distortion of this type. A priori, the net effect is ambiguous, meaning that universalism may be preferred over territorialism even if we look only at the efficiency of lending decisions by nonadjusting creditors and ignore the various other costs of territorialism. ${ }^{95}$ This is so because if enough creditors are driven to become weakly nonadjusting creditors, this cost alone could exceed that imposed by the distortion caused by universalism discussed in this Article. Ultimately, this results in inefficient lending by the creditor and a direct harm to low-risk debtors, who subsidize high-risk ones.

Because the informational demands of territorialism increase the uncertainty facing nonadjusting creditors, the magnitude of the distortion described in Part III increases. Universalism increases the distortion because creditors may find it difficult to predict the content of the bankruptcy rules that will apply to the transaction. Territorialism increases the distortion because creditors will find it difficult to predict the value of local assets that will be available in bankruptcy, the national law that will govern their claim, the nationality of other creditors, and so on. Although the relative size of the distortion created by territorialism as compared to universalism is an empirical matter, there is no a priori reason to imagine that the distortionary effects of universalism exceed those of territorialism. Thus, even looking only at the impact on weakly nonadjusting creditors - the one context in which universalism appears to impose costs - it is entirely possible that territorialism imposes even greater costs.

\section{Territorialism Frustrates Reorganizations}

Because the territorialist argument is strongest in the context of liquidations, this Article has focused primarily on that form of bankruptcy proceeding. We also must take into account, however, the effect of territorialism on the ability of a bankrupt firm to reorganize. Many bankruptcies - especially large bankruptcies - involve reorganizations. Table I reports the percentage of firms that filed under chapter 7 and chapter 11 , categorized by the size of the firm. ${ }^{96}$

95. The debtor's ability to move assets also creates strong incentives for strategic behavior by debtors and creditors. This problem will be especially severe in the case of financial assets. A debtor on the verge of bankruptcy, and receiving pressure from creditor $A$ could, for example, threaten to move its financial assets to another jurisdiction - where a different creditor will be able to collect them - if creditor $A$ does not assist the debtor through additional lending, restructuring of the debt, delays in foreclosure, etc.

96. The percentages do not add up to $100 \%$ in some rows because chapter 13 cases are not included. 
TABLE $I^{97}$

\begin{tabular}{|c|c|c|}
\hline & Chapter 7 & Chapter 11 \\
\hline Under $\$ 100,000$ & 53 & 14 \\
\hline$\$ 100 \mathrm{~K}-\$ 500 \mathrm{~K}$ & 27 & 30 \\
\hline$\$ 500 \mathrm{~K}-\$ 1 \mathrm{M}$ & 17 & 71 \\
\hline$\$ 1 \mathrm{M}-\$ 5 \mathrm{M}$ & 5 & 94 \\
\hline$\$ 5 \mathrm{M}+$ & 3 & 97 \\
\hline
\end{tabular}

As Table I shows, large firms enter into chapter 11 reorganizations much more often than chapter 7 liquidations. Because cross-border firms are likely to be large, we can infer that the firms affected by the choice of universalism or territorialism will typically be seeking to reorganize rather than liquidate. This has profound implications for the debate on international bankruptcy because it means that we should be focusing more attention on reorganizations. Once the attention turns to reorganizations, the case for universalism becomes even stronger.

Under universalism, the law of a single country governs the decision of whether or not to reorganize. The location of the assets affects the reorganization decision only to the extent that their location affects the debtor's business. ${ }^{98}$ Under territorialism, reorganization also depends on the decisions of all other relevant jurisdictions. For example, reorganization may be impossible if important assets are located in a jurisdiction that: i) does not favor reorganizations; ii) believes reorganization is inappropriate in this case; or iii) feels its local creditors can be satisfied out of local assets. Thus, reorganization depends on the agreement and cooperation of every jurisdiction in possession of firm assets. If, for example, courts in every country adopt a test that permits reorganization only when local creditors fare better under such a scheme ex post, ${ }^{99}$ then any given court system will cooperate only if the return to its local creditors under a reorganization exceeds the return to those creditors under a liquidation.

In the end, it is clear that a value-maximizing decision on reorganization requires a centralized procedure. Universalism offers a much better framework for reorganizations because it puts all assets of the firm under the control of a single court. Allowing each jurisdiction to

97. Data are taken from Elizabeth Warren \& Jay Lawrence Westbrook, Financial Characteristics of Businesses in Bankruptcy, 73 AM. BANKR. L.J. 499, 524 tbl.2A (1999).

98. For example, a production facility in a country that is in the midst of severe political turmoil is worth considerably less than one in a country that is at peace.

99. This approach is suggested by 11 U.S.C. $\S 304$, and is essentially the inquiry undertaken by the courts in In re Toga and Interpool Ltd. v. Certain Freights of the M/V Venture Star, 102 B.R. 373 (D.N.J. 1988), see supra text accompanying notes 35-41. 
arrive at its own conclusion is akin to giving each creditor - or at least the creditors of each country - a veto over reorganizations. It is certain to lead to the liquidation of enterprises that would be more valuable as going concerns. Any serious consideration of territorialism, therefore, must account for the tremendous difficulty associated with reorganizing a firm under that regime. The inability of a territorialist regime to deal effectively with reorganization ultimately presents one of the largest problems with that approach.

\section{Critiques of Universalism}

In a recent article, Professor LoPucki argues in favor of a form of territoriality that he calls "cooperative territoriality." 100 His article, along with his contribution to this symposium, represent by far the most significant defense of territorialism, and therefore deserves a direct response. This Section demonstrates that the arguments advanced by LoPucki, with the exception of arguments that turn on the presence of nonadjusting creditors and that have already been addressed, do not represent a serious challenge to universalism. To make this response as clearly and directly as possible, this Section will address each of Professor LoPucki's arguments in the order he advances them in his 1999 article.

\section{Foreign Law and Courts Governing Domestic Relationships}

The first of LoPucki's concerns is that a domestic debtor-creditor relationship would be subject to the bankruptcy rules of a foreign jurisdiction. ${ }^{101}$ "[I]n a universalist system, the priority of Mexican workers against a U.S. firm operating in Mexico would be determined by U.S. rules of priority - much to the disappointment of the Mexican workers affected." 102

There appear to be three components to this point. First, there is a concern that nonadjusting creditors will fail to take into account the applicable bankruptcy rules under universalism. This Article has, of course, responded to this concern at length above and, in particular, shown that the recovery of employees is not very sensitive to the choice of regime. ${ }^{103}$

The second concern is that, even if adjustment were possible, "it would create a stiflingly complex domestic interface for the international bankruptcy system. Presumably, sellers would adjust the prices

100. LoPucki, Cooperation, supra note 2, at passim.

101. See id. at 709-13.

102. Id. at 711.

103. See supra Section IV.A.3. 
of all goods and services sold on credit in the domestic economy to reflect the bankruptcy priority of the seller under the law of the debtor's home country." 104 We would expect this, of course, if all creditors were adjusting. Furthermore, this yields the efficient outcome. If all creditors adjust, they will structure their out-of-bankruptcy contracts to ensure that they receive a market rate of return in expectation. In other words, creditors will price their credit appropriately - causing credit to flow to its most productive uses, and ensuring that projects with a positive expected value will be carried out while those with a negative expected value will not. Rather than a cause for concern, this is a goal to strive for.

Finally, LoPucki seems uncomfortable with the notion that the country in which assets are located cannot adjudicate the distribution of those assets in accordance with its own values and concerns. This loss of sovereignty implies that the country in which the assets are located must allow its values to be trumped by the values of the main jurisdiction. LoPucki's argument, however, overlooks the fact that any solution to the choice of law problem posed by a transnational bankruptcy will involve the loss of sovereignty of one country - this is an unavoidable consequence of international business activity. Under universalism, as LoPucki points out, the country in which the assets are located must yield to the main jurisdiction (where these are not the same country). He claims that, as a result, creditors in the host country will suffer prejudice. ${ }^{105}$

The story, of course, could be told from the opposite perspective. Imagine, for example, a bankruptcy in which assets are located in Mexico (and perhaps elsewhere), creditors are located in both the United States and Mexico, and the home jurisdiction under universalism would be the United States. ${ }^{106}$ That the home jurisdiction is the United States suggests that the firm has closer ties to the United States than to Mexico. ${ }^{107}$ To the extent the bankruptcy rules differ between the United States and Mexico, a choice of one regime over the other will offer an ex post benefit to some creditors while harming others. Choosing Mexican law for the adjudication of the assets requires the subordination of United States law and policy to those of Mexico. Despite the fact that the debtor is more closely associated with the United States than with Mexico (as evidenced by the fact that the United States is the home jurisdiction) and the fact that at least some of the creditors are in the United States, American values are subor-

104. LoPucki, Cooperation, supra note 2 , at 711.

105. See id.

106. This is the example used by LoPucki, who concludes that turning the assets over to U.S. jurisdiction is undesirable because Mexico loses its ability to implement its system of bankruptcy values. See id. at 710-12.

107. See infra note 108 (discussing the determination of the home jurisdiction). 
dinated. $^{108}$ This leaves the United States unable to implement its own value system just as much as choosing United States bankruptcy law would frustrate Mexican goals (and perhaps more because of the debtor's close association with the United States). The important point is that the distribution of assets (ignoring transaction costs, which, as this Article has argued, are lower under universalism) is a zero-sum process. The choice-of-law problem is, as a result, also zero sum - where the values of two countries conflict, one must be chosen at the expense of the other. The value of assets whose distribution is affected by the choice of law regime represents the loss of sovereignty of one country in favor of that of another. This fact is an unavoidable part of the choice of law decision. Put simply, international business activity requires the compromise of certain notions of national sovereignty because many countries may have an interest in the fate of debtors and their creditors.

\section{Indeterminacy of the "Home Country" Standard}

For universalism to work, of course, one must identify the "home country" of the debtor. In the purest form of universalism, the governing law is that of the "main" jurisdiction, defined as the home country of the debtor. ${ }^{109}$ Possible approaches for defining the main jurisdiction include the place of incorporation, the principal place of business, ${ }^{110}$ and the "center of main interests." should drive the choice are the ease with which the home country can be identified and the ease with which the debtor can choose or select the applicable law. The parties to a transaction must know which is the main jurisdiction in order to adjust the terms of the loan appropriately, but if it is too easy for the debtor to change the main jurisdiction, it could choose in such a way as to disadvantage strongly nonad-

108. It might be argued that the plausible candidates for determining the home jurisdiction will sometimes choose a jurisdiction that is, at least arguably, not the one with the greatest connection to the debtor. Even if that is true, it is clear that in the vast majority of cases, the home jurisdiction will be a good proxy for the country most interested in the debtor.

109. Under a contracting regime, like the one suggested by Rasmussen, the relevant jurisdiction would be whatever was chosen by the debtor ex ante. See Rasmussen, supra note 2.

110. See Trautman et al., supra note 6, at 580; Trautman, Foreign Creditors, supra note 4 , at 55 (arguing for the principal place of business test).

111. This is how the UNCITRAL Model Law on Cross-Border Insolvency identifies the home country. See UNCITRAL MODEL LAW ON CROSS BORDER INSOLVENCY WITH GUIDE TO ENACTMENT, supra note 7, at Art. II(b); Manfred Balz, The European Union Convention on Insolvency Proceedings, 70 AM. BANKR. L.J. 485, 504 (1996) (stating that EU Convention takes the center of main interests to be "the principal place of business... [which] until proof to the contrary [is presumed to be] the place of the registered office"); Berends, supra note 7, at 329-30; European Union Convention on Insolvency Proceedings, Nov. 23, 1995, art. 3, para. 1,35 I.L.M. 1223. 
justing creditors that are likely to interact with the firm. This, in turn, would generate an incentive for countries to provide regimes that grant nonadjusting creditors a low priority. For this reason, a test based on the place of incorporation would be inappropriate. ${ }^{112}$ A test such as the principal place of business, on the other hand, is much more difficult for the debtor to manipulate. ${ }^{113}$ Determining the main jurisdiction using, for example, the principal-place-of-business test or the center-of-main-interests test, typically will be easier than attempting to identify the location of all the debtor's assets - including financial assets and future assets - which may be spread among many jurisdictions and which may be moved at any time. Also note that under territorialism a debtor may have an incentive to mislead a creditor regarding the location of assets in order to make the creditor believe it faces a favorable bankruptcy regime. The creditor, therefore, must independently verify the location of all assets.

Professor LoPucki claims that the lack of agreement over the standard to use in identifying the home country represents a serious problem for advocates of universalism, stating that "the home countries of a substantial number of companies remain in doubt."114 To the extent that he refers to the fact that no single test has emerged as the preferred test, his critique relates to the implementation of universalism, and not to its merit. There is no doubt that a universalist system should choose a single test to determine the home jurisdiction, but this does not constitute a reason to prefer territorialism.

If Professor LoPucki refers instead to the fact that, under any test, close cases will arise in which the home country is difficult to identify, his claim that there are many such cases conflicts with the views of most commentators. In fact, there is widespread agreement among those interested in transnational insolvency that, in the vast majority of cases, the home country will be easy to identify - making the issue a minor question. ${ }^{115}$ In those few cases where ambiguity exists, creditors must take that uncertainty into account when they negotiate the

112. One could give the debtor the ability to select the main jurisdiction at the time of incorporation as long as nonadjusting creditors are protected. This would require some form of cooperation among countries to fix the priority status of these creditors. This point has been made in both the domestic and international debates. See Barry Adler, Financial and Political Theories of American Corporate Bankruptcy, 45 STAN. L. REV. 311, 339-40 (1993); Rasmussen, supra note 2, at 21-22; Alan Schwarz, Contracting About Bankruptcy, 13 J.L. ECON. \& ORG. 127 (1997).

113. Note that whichever test is used, it would be best for a single criteria to serve as the determining factor (e.g., the principal place of business) in order to promote clarity and predictability.

114. LoPucki, Cooperation, supra note 2 , at 713.

115. See Rasmussen, supra note 2 , at 12 ("In most situations, it will be clear which country is the home of the debtor."); Westbrook, Choice of Law, supra note 2, at 529 ("Although circumstances will exist in which determination of the home country of a corporation will be difficult, it will usually be self-evident."). 
loan. Although this will introduce inefficiency in some cases, creditors rarely will need to consider more than two jurisdictions. Contrast this outcome with territorialism, under which creditors must consider the laws of all jurisdictions in which assets are located, or into which assets may move.

It does not suffice, of course, merely to point out that occasional problems will arise with identifying the home country. Although no one could seriously claim that the choice of law problem in transnational bankruptcies - regardless of the rule adopted - will be simple in every case, the proper question is not whether the home country standard is fully predictable in one hundred percent of the cases, both real and imagined, but rather, whether it provides greater total benefits than the possible alternatives. This, of course, brings us back to a comparison of the relative merits of territorialism and universalism. On the issue of predictability, it seems that universalism presents the better choice. While occasional cases may occur in which the identity of the home country remains in doubt, a territorial approach based on the future location of assets - including mobile assets, financial assets, and assets not yet acquired - clearly does not present a more predictable choice of law rule. Basing jurisdiction on the home country of the debtor, regardless of which definition of home country is used, ${ }^{116}$ leads to greater certainty than does a territorial approach.

Professor LoPucki does not deny that the removal of assets on the eve of bankruptcy is a serious problem for territorialism. He argues, however, that the problem can be solved within a territorialist framework. Under his system, assets would be "located" in a country if that country were able to exercise power over them. ${ }^{117}$ The idea is that only a small number of countries will have this ability over any given asset at any given time. As a result, he argues, this system provides a reasonably clear rule.

This approach is difficult to square with Professor LoPucki's general argument that a universalist system leaves the identity of the home country indeterminate. In order to lend efficiently, a creditor needs to know, at the time of contracting, which legal regime's rules will control the distribution of assets in a bankruptcy. Professor LoPucki's proposed rule would lead to much greater uncertainty regarding the applicable law than would a universalist regime. First, Professor LoPucki concedes that more than one country may have the Bankruptcy, 98 MICH. L. REV. 2216, 2219-20 (2000). 
ability to control an asset at the time of bankruptcy, making the applicable bankruptcy rule uncertain..$^{118}$

Second, recognizing that the problem of strategic removal of assets is a serious one under territorialism, ${ }^{119}$ he proposes the establishment of treaties to ensure that such assets are returned to the country in which they were located during the pre-bankruptcy period. Professor LoPucki does not provide further details regarding the treaties he has in mind. Instead, he argues that the problem of strategic removal is small because creditors can contract to prevent such removal, and local law can criminalize extreme versions. ${ }^{120}$ It is true that contractual solutions to the problem of removal are possible, but they come at significant cost. Notice that the problem here is much greater than the strategic removal of assets on the eve of bankruptcy. It includes the movement of assets at any time after the creditor lends to the debtor. Such movement undermines the efficiency of the lending process. The sort of restrictions on the movement of capital that Professor LoPucki cites as a solution to the problem of capital movement, therefore, would restrict such movement for the entire life of the loan. If creditors impose restrictions on the movement of assets, they limit the ability of the firm to pursue opportunities abroad. This represents both a private and social cost that is avoided through universalism. ${ }^{121}$ Establishing a system that encourages such contractual conditions on all large-debt contracts represents a significant constraint on international capital mobility. ${ }^{122}$

Although the above arguments support universalism, they also provide support for the contract-based approach advocated by Professor Rasmussen. ${ }^{123}$ Under his proposed regime, a debtor would choose its "home" country at the time of incorporation. Because this choice takes place before the corporation has any creditors, all creditors can adjust the terms of their lending to take the chosen regime into account. $^{124}$ The key difference between the contracting approach and universalism is that the former gives debtors the ability to make a one-

118. See LoPucki, Cooperation, supra note 2, at 743 ("Often more than one country will have [de facto power over assets], necessitating further agreement to fix a single location."). Professor LoPucki does not specify the sort of further agreement that he has in mind.

119. See id. at 758 ("The problem of strategic removal of assets on the eve of bankruptcy would be more severe under territorialism than universalism.").

120. See id.

121. A more detailed discussion of the problem with private solutions to territorialism can be found in Bebchuk \& Guzman, supra note 2, at 800-02.

122. See supra note 92.

123. See Rasmussen, supra note 2; Robert K. Rasmussen, Resolving Transnational Insolvencies Through Private Ordering, 98 MrCH. L. REV. 2252 [hereinafter Rasmussen, Private Ordering].

124. See Rasmussen, supra note 2, at 5. 
time choice of the applicable law at the time of incorporation. The addition of such choice should lead to an increase in efficiency and welfare, as Professor Rasmussen argues, making the choice-based approach an attractive option.

As a theoretical matter, there is little to criticize about the contract model. The most serious problem with a contracting model is the potential incentive it may provide to lawmakers to establish "debtor havens." Rasmussen recognizes this problem and argues convincingly that the magnitudes involved are likely to be small. ${ }^{125}$ In his view, debtor havens remain an issue only for tort creditors, and for this group he proposes that "any bankruptcy regime selected by a firm accord at least nominal priority to tort victims similar to what they achieve in their home country." 126 In my view, Rasmussen's approach to the debtor haven question resolves any concern that a choice-based system would cause strategic behavior by national governments trying to take advantage of nonadjusting creditors. If additional creditors are deemed strongly nonadjusting, they should receive the same treatment as tort creditors.

The primary difficulty with a contract-based system is not that it somehow represents bad policy, but rather that it is incomplete. In the absence of a mechanism for changes in the chosen bankruptcy regime, the contracting regime will typically lead to outcomes identical to a universalist regime, because firms typically will choose the applicable regime long before they engage in transnational activities. At the time of incorporation, a firm cannot be expected to anticipate its future structure and future bankruptcy needs. Indeed, even a cursory examination of available bankruptcy regimes may represent a cost that outweighs the benefits for a new corporation, because that firm's business activities normally will be domestic in nature when it begins operations, making a choice of the local regime likely. Thus, where a firm exercises choice at the time of incorporation, one normally would expect it to choose the local regime - making the system identical to universalism.

Under a contract-based regime, of course, lawmakers would need to adopt default rules for those cases in which no regime was explicitly chosen. The search for a default rule leads us back to the question of whether territorialism or universalism is preferable. For all the reasons advanced by supporters of universalism, that system would represent the better default rule.

An additional problem may arise in the implementation of a choice-based international regime alongside a mandatory domestic re-

125. Rasmussen's arguments are, in many ways, similar to those advanced in this Article. See Rasmussen, Private Ordering, supra note 123, at 2264-74 (discussing debtor havens).

126. Id. at 2271. 
gime. A firm that starts its business without any international connections would be subject to the domestic regime, regardless of its attempts to choose another regime at the time of incorporation. When the firm becomes a "transnational firm" (however defined), it would then receive the benefit of its choice of regime. Such a change in applicable bankruptcy regime, of course, would impact existing creditors in a way that introduces distortions in the firm's investment decisions. ${ }^{127}$ In fairness to Rasmussen, he also has advocated a choicebased approach to domestic bankruptcy, and if choice were adopted in both the domestic and international context, the treatment of domestic and international firms would become consistent. Rasmussen's proposal, therefore, requires much more sweeping changes to the bankruptcy laws. Universalism, on the other hand, does not require any adjustments to the domestic system.

\section{The Extent of Jurisdiction of Corporate Groups}

LoPucki accurately points out that large firms often operate as a group of separately incorporated firms rather than as a single transnational entity. Should such a group be handled as a single enterprise in bankruptcy, or should it be treated as a series of independent firms (perhaps each with its own bankruptcy filing)?

The presence of corporate groups clearly complicates the adjudication of a transnational insolvency. This is true under either territorialism or universalism. Under universalism, the danger is that creditors must take into account the manner in which the home country of a parent corporation will treat the group. If the subsidiary will be considered part of the group and, therefore, brought into a bankruptcy in the parent's home country, the bankruptcy law of that country will have to be taken into account. On the other hand, if the subsidiary will be treated as an independent entity, the bankruptcy law of the home country of the subsidiary is the relevant one. Needless to say, this complicates the analysis facing an adjusting creditor, and increases the distortion caused by weakly nonadjusting creditors. ${ }^{128}$

Once again, however, the relevant question is not whether universalism makes transnational bankruptcies work as well as domestic bankruptcies, but rather, whether it offers a better solution than territorialism. Territorialism provides creditors with predictability inasmuch as creditors can be sure that local law will govern the distribu-

127. See Bebchuk \& Guzman, supra note 2.

128. Another consequence of the presence of corporate groups may also be to increase the number of weakly nonadjusting creditors. If the manner in which the home country of the parent will decide whether or not to exercise jurisdiction over the subsidiary is unknown or unpredictable, creditors who would normally be adjusting creditors may be forced to behave like weakly nonadjusting creditors with respect to the subsidiary. 
tion of local assets. What territorialism cannot provide, however, is any certainty regarding the share of the group's assets that will be within the jurisdiction at the time of filing, or a workable mechanism for reorganizations.

Note first that the existence of corporate groups is a manageable problem for adjusting creditors. Secured creditors, for example, often solve the problem by taking a security interest not only in the assets of the debtor, but also in the assets of related corporations - either parents or subsidiaries. The bankruptcy of the debtor triggers a default on the loan and permits collection efforts against other members of the corporate family. As a result, secured creditors can effectively bring the assets of the entire corporate family within their reach. Under a universalist regime, the creditor can then recover in bankruptcy from the family members that are included in the estate and out of bankruptcy from those family members that are outside the estate. Largely the same result will come about under a territorialist regime, except that the creditor must pursue recovery in separate bankruptcy proceedings in each country in which assets are located - increasing collection costs. Furthermore, under territorialism, the decision of which members of the family will be put into bankruptcy will be made independently by national courts. This encourages a race to the courthouse in cases where some members of the corporate family are not yet in bankruptcy, and a duplication of litigation, across jurisdictions, regarding whether or not to put a member of the family into bankruptcy.

Second, as a corporate group approaches bankruptcy, there may be significant transfers of value from one member of the corporate group to another. This may be done, for example, in an attempt to stave off bankruptcy through restructuring or to pay off important debtors on whom the debtor needs to rely post-bankruptcy. This sort of planning prior to bankruptcy renders a territorialist approach highly unpredictable. A debtor that hopes to reorganize, for example, will have a strong incentive to place as many assets as possible in a jurisdiction that makes reorganization possible. Even if the debtor intends to liquidate the firm, some jurisdictions may allow equity holders to extract value while others may not - giving the debtor more reason to locate assets strategically.

The existence of corporate groups also aggravates the problem of reorganization because effective reorganization may require jurisdiction over several separately incorporated members of the group. It is important to note, however, that this results not from the existence of a universalist regime, but rather from the existence of corporate groups. Under a universalist regime, the existence of corporate groups makes reorganization somewhat more difficult but still possi- 
ble. Under a territorialist regime, however, reorganization is virtually impossible. ${ }^{129}$

Although the problem of corporate groups does not justify a move to territorialism, it does provide a reason to seek cooperation among national governments in the implementation of a universalist bankruptcy regime. For example, if governments could agree on how to determine the extent of the bankrupt estate, the adjustment of creditors would be simplified. A creditor would only need to consider a single rule in order to understand which parts of the corporate group would fall within the bankruptcy.

In order to demonstrate that universalism can handle the corporate groups problem as well as territorialism, consider the following approach. ${ }^{130}$ Suppose that every separately incorporated entity is treated as an independent firm with its own bankruptcy proceedings. Several disadvantages come to mind immediately. First, reorganization of the entire group will be very difficult. Second, creditors will recover based on the assets of a specific member of the group, and the pre-bankruptcy debtor may have moved assets from one group member to the other. ${ }^{131}$ Finally, costs are imposed on creditors that must file in multiple bankruptcy proceedings, and upon the courts that must hear the cases. These costs, however, are quite similar to the costs of territorialism. Indeed, a debtor could structure its dealings in order to replicate the outcome that would exist under territorialism by incorporating a single, separate entity in each jurisdiction and giving that entity ownership of all local assets. The point of this example is not to advocate a rule that would treat every incorporated entity as a separate firm for bankruptcy purposes, but rather, to demonstrate that even such a crude rule will perform as well as territorialism. With even a minimal level of international cooperation, the problem of corporate groups can be resolved more easily under universalism than under territorialism.

Furthermore, although a full analysis of how to handle the problem of corporate groups lies beyond the scope of this Article, one can easily imagine strategies superior to the "one incorporation-one bankruptcy proceeding" approach mentioned above - implying, of course, that it is easy to identify approaches that deal with the issue more successfully than does territorialism. For example, a rule giving the home country of a parent corporation jurisdiction over its subsidiaries, sub-

129. See supra Section IV.B.4 (discussing reorganization under territoriality).

130. This approach is not presented as an optimal strategy. There is almost certainly a better way to handle corporate groups. Rather, it is to demonstrate that even with this unsophisticated and simple strategy it is possible to handle the problem of corporate groups more successfully than would be done under territoriality.

131. In this situation, of course, the creditor may be able to protect itself through private contract, but doing so will restrict capital mobility and the flexibility of the debtor. 
ject to a requirement of a certain level of integration, would preserve many of the benefits of universalism. It would, of course, reduce the certainty enjoyed by creditors who, in some cases, may be uncertain about whether a jurisdiction will extend to certain subsidiaries, ${ }^{132}$ but this uncertainty will be considerably less than it would be under territorialism, where the future location of the assets is entirely unpredictable.

\section{Strategic Manipulation of the "Home Country" Standard}

Finally, LoPucki argues that the "home country" standard provides debtors with the incentive and the ability to engage in forum shopping. ${ }^{133}$ Forum shopping in the international context is clearly undesirable, ${ }^{134}$ but this point weighs in favor of universalism, not territorialism. Once again, the appropriate question is not whether one could imagine a situation in which universalism fails to achieve the best imaginable outcome, but rather whether universalism or territorialism brings us closer to that outcome.

The risk of forum shopping presents a serious problem for territorialism because, under that regime, it can be accomplished simply by moving assets from one jurisdiction to another. In order to deter forum shopping, a universalist regime must avoid identifying the home jurisdiction based on easily changeable criteria, such as the place of incorporation. Criteria for identifying the home jurisdiction and that are costly to change, however, are easy to find. ${ }^{135}$ A test based on the main location of firm activity or the location of assets, for example, would be very costly for the firm to change, and would therefore deter forum shopping. Where the criteria for identifying the home country are sufficiently costly to manipulate, no more than a tiny number of firms would be induced to make such a change in order to capture the benefits of a particular forum.

\section{CONCLUSION}

If the debate regarding the regulation of transnational bankruptcies is to move forward, those who support universalism must address, in very specific terms, the arguments advanced by its opponents. To

132. Though creditors normally will be able to narrow the potential number of applicable jurisdictions to a very few.

133. See LoPucki, Cooperation, supra note 2, at 720-21.

134. See id. at 721 . The most serious problem with forum shopping would be that it would systematically disadvantage strongly nonadjusting creditors, including creditors in existence when the debtor enters the forum. See Bebchuk \& Guzman, supra note 2, for a discussion of how this can generate costs in the international context.

135. See supra text accompanying note 114 . 
date, the most popular and persuasive of those arguments has been an appeal to the plight of local creditors. If local creditors are adjusting creditors, however, they simply are not better off under territorialism. This Article also demonstrates that the efficiency arguments for universalism remain strong even in the presence of nonadjusting creditors. Although universalism magnifies the risk-based distortion in lending by nonadjusting creditors, the magnitude of the impact is almost certainly small. Furthermore, territorialism has its own way of aggravating the distortion by increasing the number of nonadjusting creditors. Thus, even if one looks only at the implications for nonadjusting creditors, territorialism cannot be shown to be a superior approach. If one looks more broadly at the issue of transnational bankruptcies, taking into account factors such as the informational demands of each regime and the impact of each on reorganization, it becomes clear that the case for territorialism is weak. Finally, it is worth noting that this Article has understated the benefits of universalism and the costs of territorialism. In order to avoid a repetition of arguments already in the literature, this Article has not discussed factors such as the cost of multiple adjudications under territorialism, the improved capital allocation under universalism, and the increased liquidation value under universalism. ${ }^{136}$ Those well-established arguments, as well as those advanced in this Article, make the case for universalism over territorialism compelling. 